\title{
Processing and Characterization of Porous Titanium for Orthopedic Implant Prepared by Argon-atmospheric Sintering and Arc Plasma Sintering
}

\author{
Dhyah Annur " *1), Fendy Rokhmanto ${ }^{b}$, Yudi Nugraha Thaha ${ }^{b}$, Ika Kartika ${ }^{b}$, Arbi Dimyatic, \\ Sugeng Supriadid, Bambang Suharno ${ }^{a}$

\begin{abstract}
${ }^{a}$ Universitas Indonesia, Faculty of Engineering, Department of Metallurgy and Materials Engineering, Depok, Indonesia.

${ }^{b}$ Indonesian Institute of Sciences, Research Center for Metallurgy and Materials, Puspiptek, Banten, Indonesia.

'Indonesian National Nuclear Energy Agency (BATAN), Center for Science and Technology for Advanced Materials, South Tangerang, Banten, Indonesia.

${ }^{d}$ Universitas Indonesia, Faculty of Engineering, Department of Mechanical Engineering, Depok,
\end{abstract} Indonesia.

Received: March 10, 2021; Revised: July 30, 2021; Accepted: August 15, 2021

\begin{abstract}
Porous titanium is proposed to be an effective orthopedic implant with a lower elastic modulus and supports osseointegration during implantation. To produce porous titanium, powder metallurgy (PM) assisted with a space-holder is used in this study. Pure titanium is used as the starting material, and salt $(\mathrm{NaCl})$ is used as the space-holder. Argon-atmospheric sintering and arc plasma sintering (APS) methods are applied for the sintering process. $\mathrm{NaCl}$ content was varied from $0-40 \mathrm{wt} \%$. The temperature sintering was at $1100{ }^{\circ} \mathrm{C}$ for the argon-atmospheric sintering, and the current process was at $75 \mathrm{~A}$ for the APS. The formation of pores, total porosity, pore distribution, phase formation, and mechanical properties were examined by the optical microscope, scanning electron microscope (SEM), X-ray diffraction (XRD), and compression testing. Titanium with the addition of $20 \mathrm{wt} \%$ of $\mathrm{NaCl}$ is shown to be a potential biomaterial for the orthopedic implant, having a porosity of $38-39 \%$, the elastic modulus of 3.2-5 GPa, and the yield strength of 141-150 MPa (argon-atmospheric sintering and APS) which shown to be similar to the properties of cortical bone.
\end{abstract}

Keywords: Porous Titanium, Space-Holder, Powder Metallurgy, Argon-atmospheric Sintering, $A P S$.

\section{Introduction}

Titanium and its alloys are commonly used as orthopedic implant materials as they have high mechanical properties, high corrosion resistance, and biocompatible properties ${ }^{1}$. However, long-term implantation of titanium in the human body may cause stress shielding phenomena and bone resorption, leading to premature implant failure due to the elastic mismatch between titanium (100-110 GPa) and the bone $(4-25 \mathrm{GPa})^{2,3}$. Moreover, titanium drawback as the orthopedic implant is the bioinert character of titanium resulting in poor osseointegration ${ }^{4}$. Accordingly, lower elastic modulus titanium ${ }^{5}$ and porous structure titanium ${ }^{6,7}$ are proposed to address the stress-shielding phenomenon. Further, the porous structure can also increase the osseointegration of the titanium implants by new bone tissue . $^{8}$

Porous structure in titanium would have detrimental mechanical properties, compared to the bulk metal to reach the properties of bone. Reduction in elastic modulus is the main purpose so that the distribution pattern of stress can be improved, and as a consequence, implant loosening and bone resorption can be avoided ${ }^{6}$. Several studies and reviews

*e-mail: dhyahannur@gmail.com have shown optimum porosity to promote bone ingrowth with $20-50 \%$ porosity and $100-500 \mu \mathrm{m}$ of pore size $\mathrm{e}^{6,9-11}$.

The porous titanium manufacturing process can be approached through liquid state metallurgy such as casting or solid-state processing such as powder metallurgy (PM). However, due to the high-temperature reactivity of titanium, liquid state manufacturing of porous titanium could be difficult ${ }^{12}$. Reactivity with oxygen and nitrogen might reduce the ductility, and some reactions with the mold might occur. Therefore, porous titanium fabrication through the solid-state process, by using the powder metallurgy method, is preferable because it allows a lower temperature process ${ }^{12}$. In principle, powder metallurgy of titanium foam generates porosity which is were created and maintained while bonding between particles via sintering occurs at a temperature below the melting point ${ }^{13}$. Moreover, powder metallurgy offers a near-net-shape manufacturing process which may reduce scrap metal produced during titanium manufacture.

There are several ways to produce porous titanium by using the powder metallurgy method, such as partial sintering ${ }^{14}$, bubble entrapment ${ }^{15}$, polymer foam impregnation ${ }^{13,16}$, and space-holder technique ${ }^{17}$. However, the space-holder 
technique ${ }^{10,18}$ is beneficial because of its low-cost routes, simple process, and possibility to produce pores in various sizes. In the space-holder technique, a temporary material is added into the mixture of titanium alloy, which will be further removed through the thermal process or the dissolution process. The commonly used space-holder are $\mathrm{NaCl}^{19,20}$, ammonium bicarbonate $\left(\mathrm{NH}_{4} \mathrm{HCO}_{3}\right)^{21,22}$, carbamide ${ }^{23,24}$, $\mathrm{Mg}^{25}$, or even saccharose ${ }^{26}$.

Since titanium is highly reactive, the sintering process of the metal is conducted mainly in a high vacuum or argon atmosphere ${ }^{27}$. PM can also be modified by using arc plasma sintering (APS), a method using plasma as an energy source in the powder consolidation process to shorten the duration of the sintering process and reduce the energy consumption $^{28}$. The schematic diagram of APS is shown in Figure 1. In previous studies, APS was able to sinter some magnesium-based alloy (Mg-Zn), oxides dispersed alloy $\left(\mathrm{Fe}-25 \mathrm{Cr}-\mathrm{Y}_{2} \mathrm{O}_{3}\right)$, and also bulk titanium alloy (Ti6Al4V) in a relatively short time (less than 1 hour $)^{29-31}$.

In this study, porous titanium was produced by using $\mathrm{NaCl}$ as the space-holder, while the sintering process was conducted under argon atmosphere and the APS. The effect of the $\mathrm{NaCl}$ content on the pore formation and the sintering process would be studied to achieve a high performance of porous titanium for orthopedic implants.

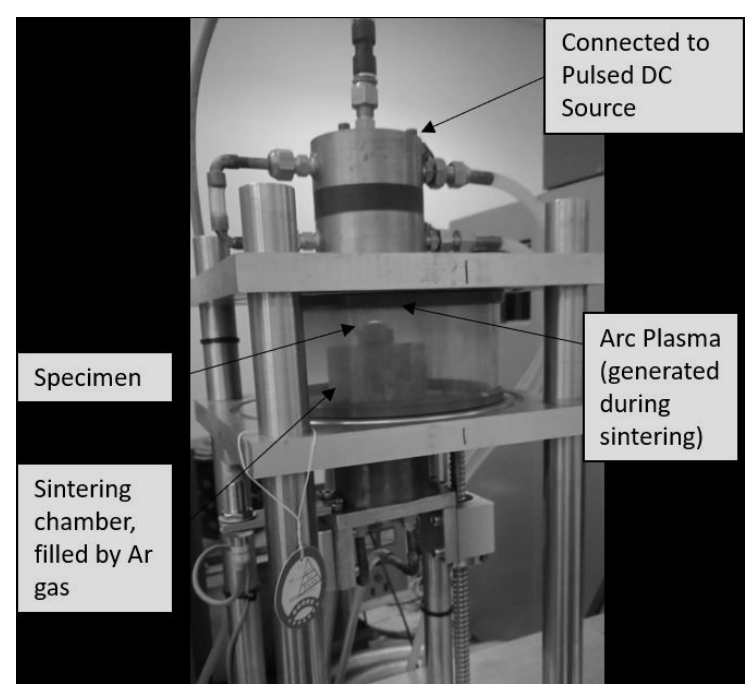

Figure 1. Schematic Diagram of APS.

\section{Materials and Methods}

\subsection{Materials}

Commercially produced pure titanium powder (CP-Ti) supplied by Chengdu Huarui Industrial China was used as the starting powder. The space-holder used was $\mathrm{NaCl}$ provided by Merck. The weight ratio of Ti powder to $\mathrm{NaCl}$ was controlled to have a specified composition of $0-40 \mathrm{wt} \% \mathrm{NaCl}$ (equal to $0-58$ vol\%). Binder was not used in the mixture to prevent additional oxidation and impurity. The detailed composition and the processing parameter of each specimen and its code are shown in Table 1.

\subsection{Processing of porous titanium}

In order to prepare porous titanium, the blend of $\mathrm{Ti}-\mathrm{NaCl}$ powder was mixed in a shaker for 30 minutes. The volume for each mixture was fixed to a specific value then uniaxially pressed at a pressure of $560 \mathrm{MPa}$ for 3 minutes to form the green compacts. The green bodies had a shape of a cylinder having a diameter of $15 \mathrm{~mm}$. The green compacts were sintered under two conditions; the first condition would be under the argon-atmospheric tube furnace (argon-atmospheric sintering route). In contrast, the second condition would be done inside the Arc Plasma Sintering device (APS route).

For the argon-atmospheric sintering route, a preheat treatment was conducted to remove the space-holder. The green bodies were preheated at $800{ }^{\circ} \mathrm{C}$ for 2 hours, followed by the sintering process at $1100{ }^{\circ} \mathrm{C}$ for 2 hours with a heating rate equal to $5{ }^{\circ} \mathrm{C} /$ minute. Finally, the samples were furnacecooled to reach room temperature. For the APS route, the samples were preheated at $50 \mathrm{~A}$ (current) for 2 minutes (turned upside down), followed by the sintering process at 75 A (current). The duration of the sintering process was varied for 2-3 minutes. The resulted porous titanium was cooled rapidly after the sintering process inside the APS device. Subsequently, the samples were ground on emery paper and ultrasonically cleaned to remove the remaining oxide layer on the surface, followed by a leaching process in distilled water. The samples were immersed in distilled water above the room temperature (the water temperature was $50-60^{\circ} \mathrm{C}$ ) for three cycles (each cycle is for 3 hours). The wet samples were dried and then weighed to ensure the dissolution of $\mathrm{NaCl}$. The leaching process was done until no further reduction on the specimen.

Table 1. Sample codes and composition.

\begin{tabular}{ccccc}
\hline \multirow{2}{*}{ Specimens Codes } & \multicolumn{2}{c}{ Composition $(\mathrm{wt} \%)$} & \multirow{2}{*}{ (vol.\% spacer) } & \multirow{2}{*}{ Sintering Condition } \\
\cline { 2 - 4 } & Titanium & NaCl & - & Argon \\
\hline Ti-0 1100 & Balance & - & 34 & Argon \\
\hline Ti-20 1100 & Balance & 20 & 47 & Argon \\
\hline Ti-30 1100 & Balance & 30 & 58 & Argon \\
\hline Ti-40 1100 & Balance & 40 & 34 & APS for 2 minutes \\
\hline Ti-20 APS 2min & Balance & 20 & 34 & APS for 3 minutes \\
\hline Ti-20 APS 3min & Balance & 20 & 47 & APS for 3 minutes \\
\hline Ti-30 APS 3min & Balance & 30 & &
\end{tabular}




\subsection{Characterization of porous titanium}

The microstructure of porous titanium was examined by using an optical microscope and a scanning electron microscope (SEM, Jeol) equipped with Energy Dispersive $\mathrm{X}$-Ray Analysis (EDX). Before the image analysis, the samples were prepared following some metallographic steps. The pore characteristics of the porous titanium were evaluated for total porosity and pore size. The total porosity was determined by the Archimedes method $\left(\mathrm{P}_{\mathrm{Ar}}\right)$ and based on image analysis $\left(\mathrm{P}_{\mathrm{IA}}\right)$. Phase formation in the sintered porous titanium was observed through $\mathrm{X}$-ray diffraction (XRD; Rigaku, $\mathrm{Cu}-\mathrm{K} \alpha$ ). Compressive tests were conducted based on ASTM E-9 by using a universal testing machine (Shimadzu) for the mechanical properties. Compression specimens were cut by an electric discharge machine followed by polishing with the SiC emery sheets.

\section{Results and Discussion}

\subsection{Preliminary evaluation of the starting powder and the salt leaching process}

The morphology of the titanium powder and the spaceholder are shown in Figure 2. These starting powders show irregular morphology. The $\mathrm{NaCl}$ particle has a wide distribution of size $(80-500 \mu \mathrm{m})$. Broad distribution particle

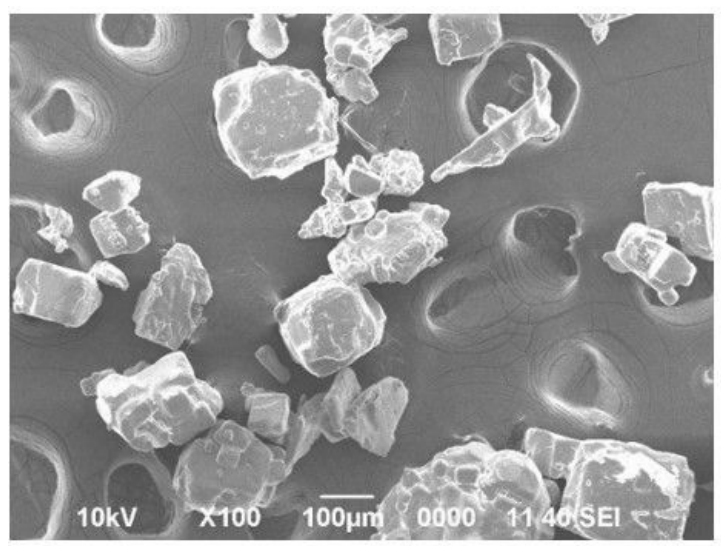

(a) size is expected to give a better interconnectivity of pores ${ }^{18}$. On the other side, irregular titanium has better mechanical interlocking than the spherical powder does ${ }^{10}$.

In the manufacture of porous titanium with space-holders, it is very likely that the residue remains. Therefore, after the sintering process, the salt leaching process should be conducted. The progressive change in the weight during the leaching process is shown in Figure 3. There is no further weight reduction on the specimen after three cycles.

\subsection{Morphology and microstructural properties}

The macro images and the microstructure images of the as-sintered samples under Argon-atmosphere are shown in Figure 4. In comparison, the APS samples are displayed in Figure 5. Further, Table 2 summarizes the pore characteristics.

Based on Figure 4, Argon-atmospheric sintering was shown to be able to produce metallic titanium. When $\mathrm{NaCl}$ was not added, as seen in Figure 4a, the pores were formed due to the incomplete densification process; therefore, the resulted pores had small sizes (micropores, only a few $\mu \mathrm{m}$ ). Meanwhile, when the $\mathrm{NaCl}$ was added (Figure $4 \mathrm{~b}-\mathrm{d}$ ), the as-sintered titanium showed two types of pores (micro and macropores).

The macropores showed a typical shape of $\mathrm{NaCl}$ confirming the function of the space-holder. Different porosities and distributions were affected by the addition of $\mathrm{NaCl}$. Increasing

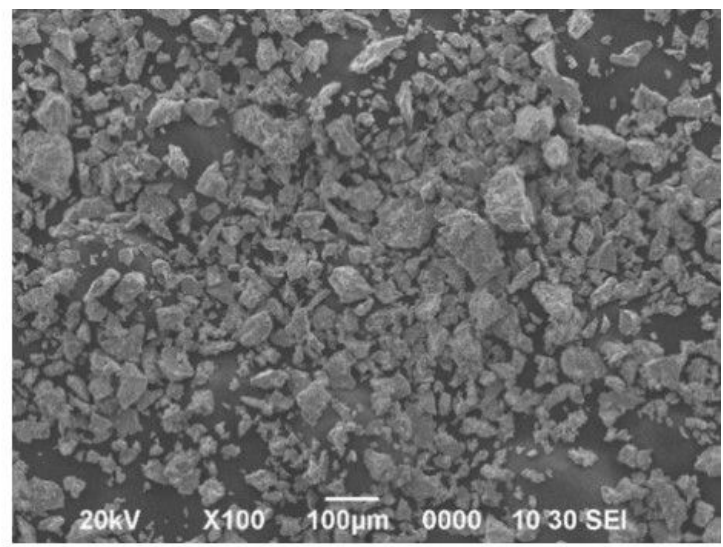

(b)

Figure 2. SEM images of a) $\mathrm{NaCl}$ powder and b) Ti powder.

Table 2. Pore characteristics of the as sintered porous titanium.

\begin{tabular}{cccc}
\hline Samples & $\mathrm{P}_{\mathrm{Ar}}(\%)$ & $\mathrm{P}_{\mathrm{IA}}(\%)$ & Macro Pore Size $(\mu \mathrm{m})$ \\
\hline Ti-0 1100 & $11.3 \pm 0.1$ & $9.2 \pm 2$ & - \\
\hline Ti-20 1100 & $39 \pm 2$ & $32 \pm 8$ & $100-800$ \\
\hline Ti-30 1100 & $49.8 \pm 1$ & $44.6 \pm 5$ & $100-800$ \\
\hline Ti-40 1100 & $58 \pm 0.3$ & $52.1 \pm 4$ & $100-800$ \\
\hline Ti-20 APS 2min & $38.1 \% \pm 3.8$ & $32.6 \pm 5$ & $100-800$ \\
\hline Ti-20 APS 3min & $38.0 \% \pm 5.6$ & $38.5 \pm 8$ & $100-800$ \\
\hline Ti-30 APS 3min & $47.5 \% \pm 0.2$ & $52.9 \pm 6$ & $100-800$ \\
\hline
\end{tabular}


$\mathrm{NaCl}$ content up to $40 \mathrm{wt} \%$ would make the pores larger and more distributed. In general, $\mathrm{NaCl}$ content has the highest effect on the formation of macroporosity. The increasing porosity based on Archimedes method and image analysis shows a similar tendency.

The corresponding porosity related to the content of $\mathrm{NaCl}$ is shown in Figure 6. Figure 6 shows a different value

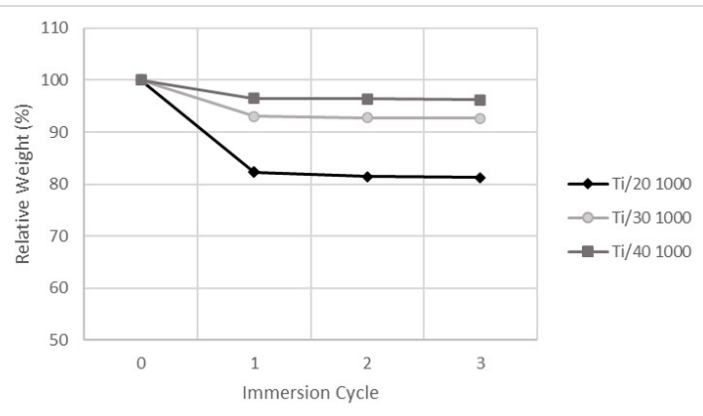

Figure 3. Reduction of weight vs immersion time.

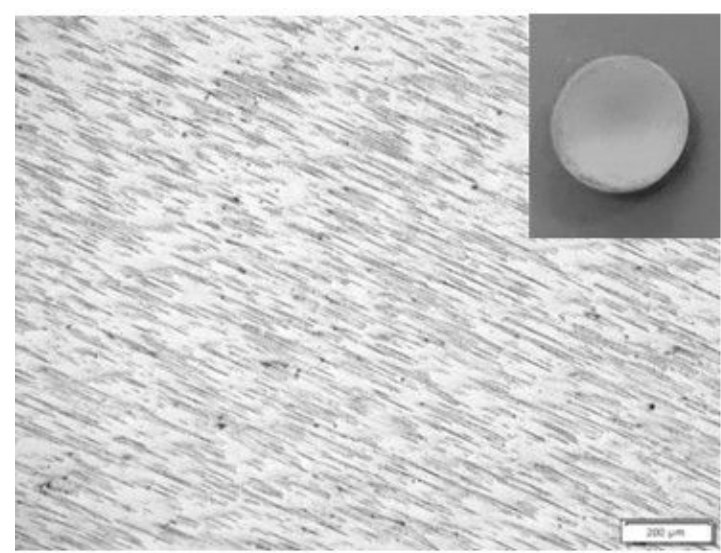

(a)

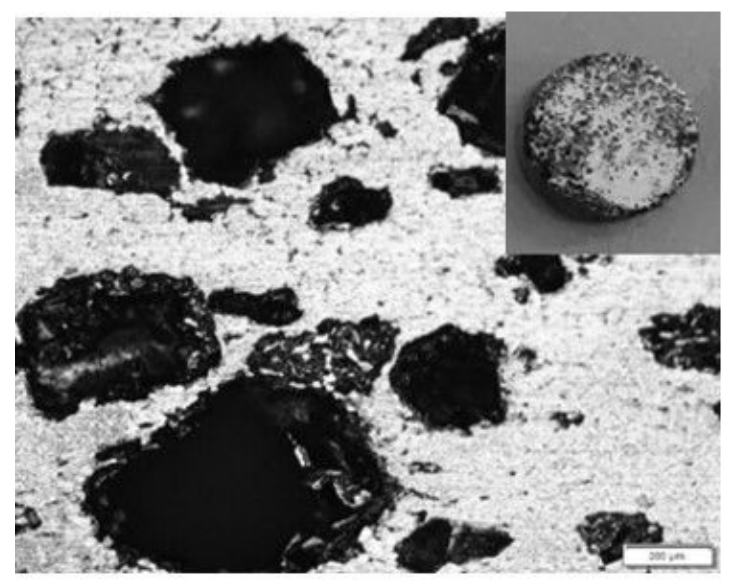

(c) between porosities based on both Archimedes method and image analysis. The Archimedes method is a volumetric method, while the image analysis would take a fraction from the total volume of the sample ${ }^{3}$. Furthermore, a higher deviation number of the $\mathrm{P}_{\mathrm{IA}}$ indicates a non-homogeneous porosity for a different observation area. The hygroscopic nature of $\mathrm{NaCl}$ may lead to the accumulation of the spaceholder. When the $\mathrm{NaCl}$ content is more than $30 \mathrm{wt} \%$, it will make the space-holder agglomerates, creating a larger pore size. The higher porosity might happen since the densification during the sintering process is not entirely conducted. Another consideration for the pore formation is when the space-holder is not fully dissolved and remains in the isolated pores.

Figure 7 shows the SEM images and the EDX detection for the as-sintered titanium. Different pore structures and pore walls can be seen more clearly. During sintering, there would be some changes: dimensional change of the pores, pore walls, and the shrinkage of the whole samples ${ }^{23}$. Since temperature sintering in this study was relatively lower than the titanium's melting temperature, the shrinkage of the entire

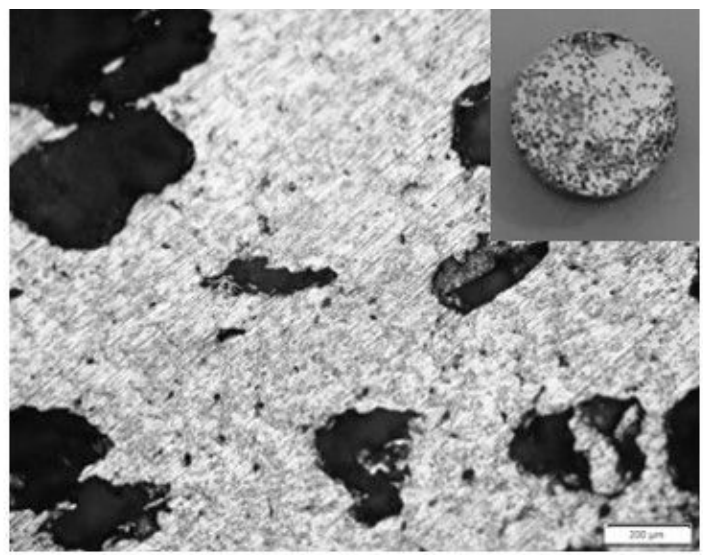

(b)

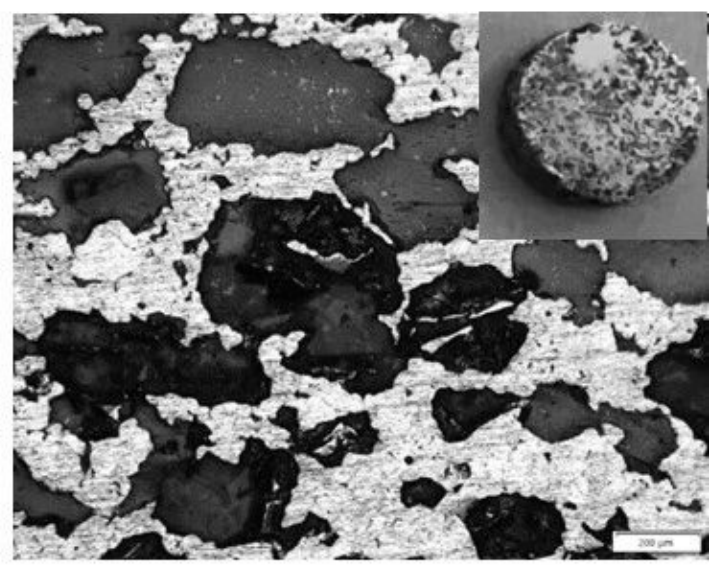

(d)

Figure 4. Photograph and optical microscope images of porous titanium prepared by Argon-atmosphere; (a) Ti-0 1100, (b) Ti-20 1100, (c)Ti-30 1100, (d) Ti-40 1100. 


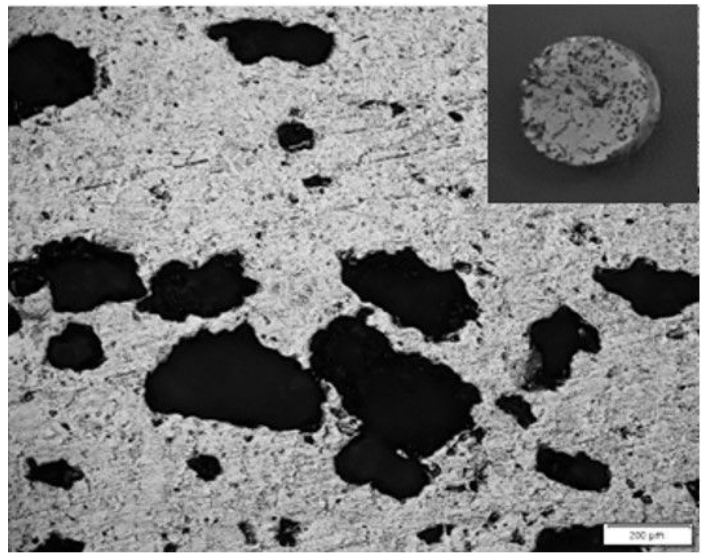

(a)

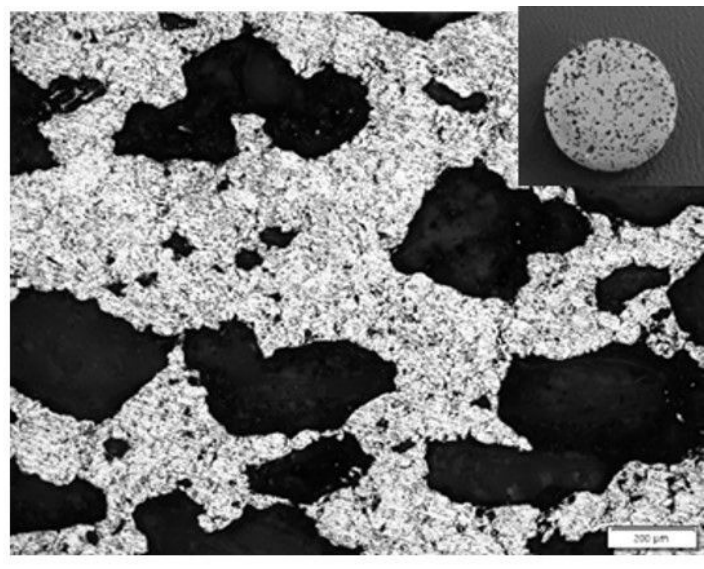

(b)

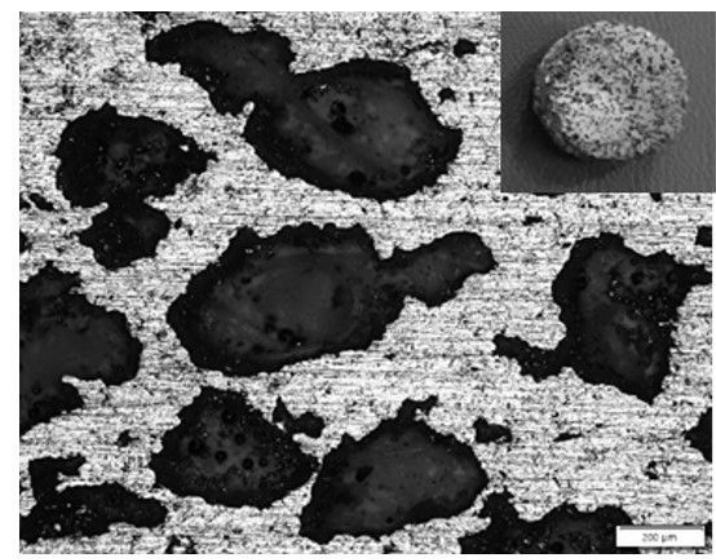

(c)

Figure 5. Photograph and optical microscope images of porous titanium prepared by APS (a) Ti-20 APS $2 \mathrm{~min}$, (b) Ti-20 APS $3 \mathrm{~min}$, (c) Ti-30 APS 3min.

(a)

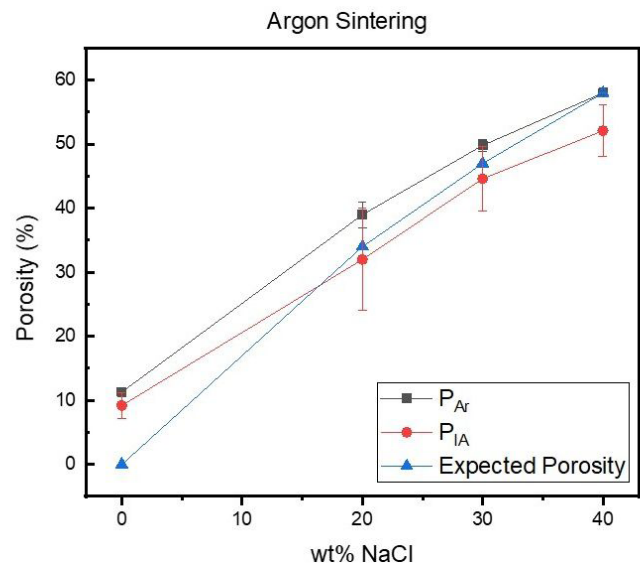

(b)

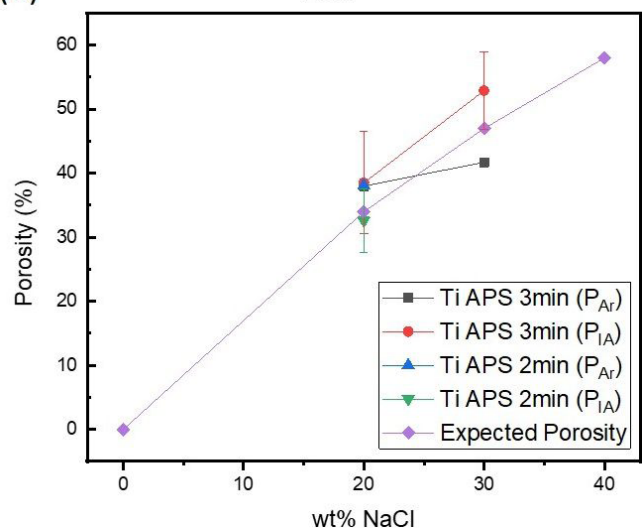

Figure 6. Corresponding porosity related to the $\mathrm{NaCl}$ for different sintering process; (a) Argon sintering, (b) APS.

specimen was insignificant. There was also no evidence of the reduction of the sample height after the sintering process.

Figure $7 \mathrm{a}$ shows the pore structure of Ti-0 1100, while the EDX reveals some impurity that remains inside the pore.
Since metallographic steps were applied to the samples, the SiC paper and the alumina paste $\left(\mathrm{Al}_{2} \mathrm{O}_{3}\right)$ might contaminate the samples. Figure $7 \mathrm{~b}-\mathrm{d}$ shows a type of irregular shapes in a macro size $(>100 \mu \mathrm{m})$. The observed pore structure 


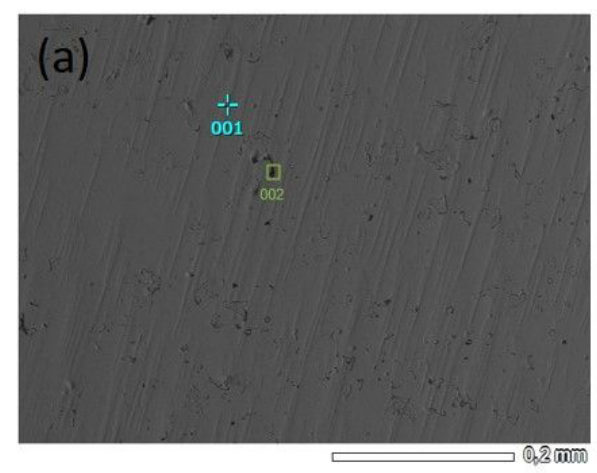

\begin{tabular}{|l|l|l|l|l|l|}
\hline No & Element & $\mathrm{keV}$ & $\begin{array}{l}\text { Mass } \\
(\%)\end{array}$ & $\begin{array}{l}\text { Error } \\
(\%)\end{array}$ & $\begin{array}{l}\text { Atom } \\
(\%)\end{array}$ \\
\hline 1 & $\mathrm{Ti}$ & 4.508 & 100 & 0.38 & 100 \\
\hline 2 & $\mathrm{Si}$ & 1.739 & 0.95 & 0.23 & 1.61 \\
\hline & $\mathrm{Ti}$ & 4.508 & 99.05 & 0.33 & 98.39 \\
\hline
\end{tabular}

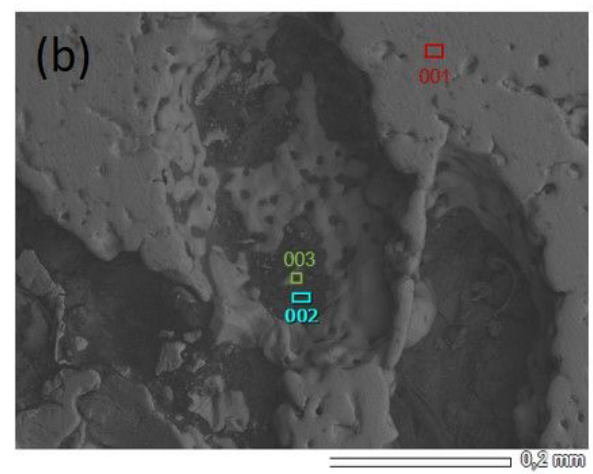

\begin{tabular}{|l|l|l|l|l|l|}
\hline No & Element & $\mathrm{keV}$ & $\begin{array}{l}\text { Mass } \\
(\%)\end{array}$ & $\begin{array}{l}\text { Error } \\
(\%)\end{array}$ & $\begin{array}{l}\text { Atom } \\
(\%)\end{array}$ \\
\hline 1 & $\mathrm{Al}$ & 1.486 & 1.15 & 0.29 & 2.03 \\
\hline & $\mathrm{Ti}$ & 4.508 & 98.85 & 0.39 & 97.97 \\
\hline 2 & $\mathrm{C}$ & 0.277 & 48.96 & 0.21 & 60.33 \\
\hline & $\mathrm{O}$ & 0.525 & 34.08 & 0.85 & 31.53 \\
\hline & $\mathrm{Al}$ & 1.486 & 11.28 & 0.2 & 6.19 \\
\hline & $\mathrm{Si}$ & 1.739 & 0.88 & 0.23 & 0.46 \\
\hline & $\mathrm{Ti}$ & 4.508 & 4.8 & 0.37 & 1.48 \\
\hline 3 & $\mathrm{Ti}$ & 4.508 & 100 & 0.37 & 100 \\
\hline
\end{tabular}

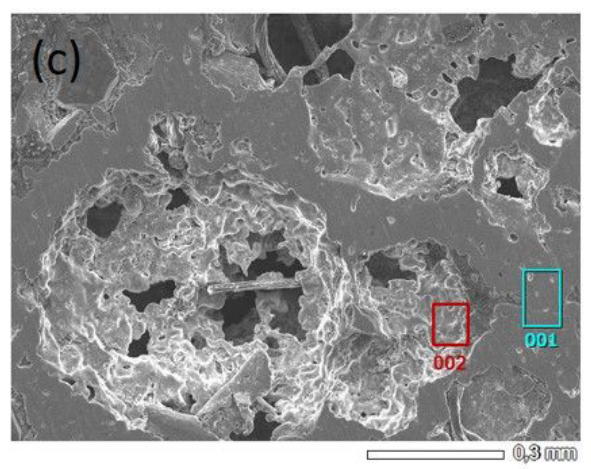

\begin{tabular}{|l|l|l|l|l|l|}
\hline No & Element & $\mathrm{keV}$ & $\begin{array}{l}\text { Mass } \\
(\%)\end{array}$ & $\begin{array}{l}\text { Error } \\
(\%)\end{array}$ & $\begin{array}{l}\text { Atom } \\
(\%)\end{array}$ \\
\hline 1 & $\mathrm{Ti}$ & 4.508 & 100 & 0.65 & 100 \\
\hline 2 & $\mathrm{C}$ & 0.277 & 11.04 & 0.43 & 31.9 \\
\hline & $\mathrm{Al}$ & 1.486 & 2.18 & 0.48 & 2.80 \\
\hline & $\mathrm{Si}$ & 1.739 & 4.73 & 0.45 & 5.85 \\
\hline & $\mathrm{Ti}$ & 4.508 & 82.05 & 0.68 & 59.46 \\
\hline
\end{tabular}

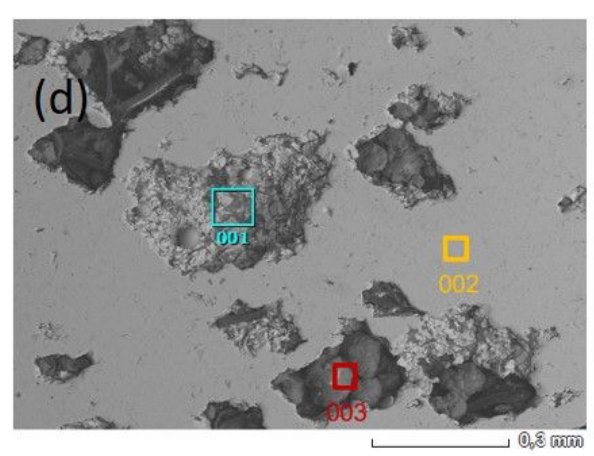

\begin{tabular}{|l|l|l|l|l|l|}
\hline No & Element & keV & $\begin{array}{l}\text { Mass } \\
(\%)\end{array}$ & Error & $\begin{array}{l}\text { Atom } \\
(\%)\end{array}$ \\
\hline 1 & $\mathrm{O}$ & 0.525 & 33.69 & 0.82 & 58.12 \\
\hline & $\mathrm{Al}$ & 1.486 & 8.21 & 0.14 & 8.40 \\
\hline & $\mathrm{Ti}$ & 4.508 & 58.1 & 0.21 & 33.48 \\
\hline 2 & $\mathrm{Ti}$ & 4.508 & 100 & 0.31 & 100 \\
\hline 3 & $\mathrm{O}$ & 0.525 & 45.3 & 0.61 & 58.63 \\
\hline & $\mathrm{Na}$ & 1.041 & 0.34 & 0.52 & 0.30 \\
\hline & $\mathrm{Al}$ & 1.486 & 52.44 & 0.38 & 40.24 \\
\hline
\end{tabular}

Figure 7. SEM and EDS characterization for the porous titanium (a) Ti-0 1100, (b) Ti-20 1100, (c) Ti-40 1100, and (d) Ti-20 APS 3 min. 
(a)

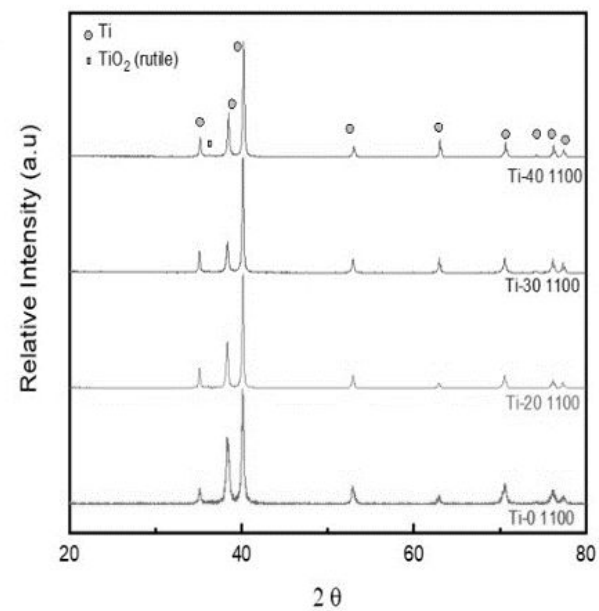

(b)

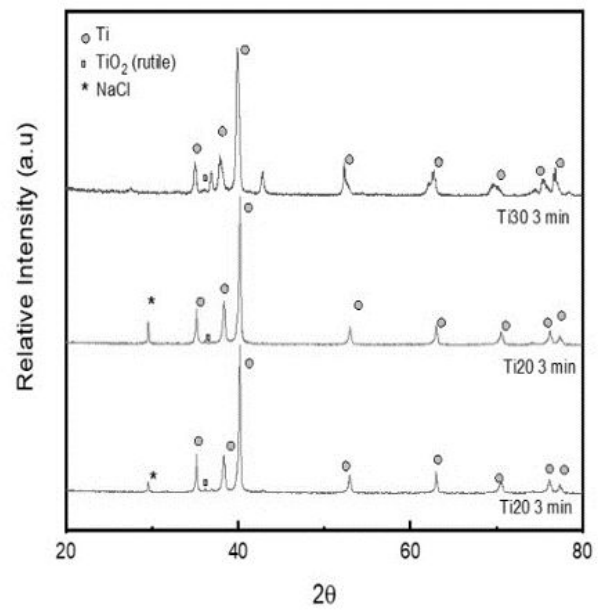

Figure 8. XRD spectra of porous titanium after (a) Argon sintering, (b) APS.

in this study was a compromise of the raw $\mathrm{NaCl}$ (cuboid, irregular, large particle size) with a wide variety of sizes and the sintering process. Figure $7 \mathrm{~b}$ shows a type of closed pores with some micropores, influenced by the addition of $20 \mathrm{wt} \%$ of $\mathrm{NaCl}$. Microporosity $(<10 \mu \mathrm{m})$ has been recognized to be an essential factor in increasing scaffold osteoinduction ${ }^{32}$.

Figure $7 \mathrm{c}$, when $40 \mathrm{wt} \%$ of the space-holder was added, shows a type of interconnected pores with macro and microporosity. Since the same sintering temperature was applied to Ti-20 1100 and Ti-40 1100, the pore walls of these specimens were also similar. The rough pore walls could be observed, implying that the densification was not finished. Figure $7 d$, when the APS is applied to the $20 \mathrm{wt} \%$ of $\mathrm{Ti}-\mathrm{NaCl}$ mixture, also shows a closed pore type, consisting of micro- and macroporosity. However, the pore walls were seen to be much rougher than in the case of Argon-atmospheric sintering, indicating that a less densification process had occurred. Further, the EDX reveals the $\mathrm{Na}$ element in the alloy. Although the APS is shown to be able to sinter the porous titanium, less processing time might also result in the incomplete process of space-holder removal. Less densification on the pore walls may deteriorate the mechanical properties of porous titanium.

Figure 8 shows the XRD pattern for the as-sintered porous titanium. Phases on porous titanium after Argonatmospheric sintering consists of Ti phases and a small peak of the $\mathrm{TiO}_{2}$ phase (Figure 8a). There is no other chemical reaction product during sintering under the Argon-atmosphere. Meanwhile, in Figure 8b, peak characteristics of porous titanium after APS consists of titanium phases, $\mathrm{TiO}_{2}$ phases, and $\mathrm{NaCl}$ phase. The $\mathrm{NaCl}$ phase in the APS specimens indicates the residue of $\mathrm{NaCl}$. It means the leaching process could not remove the space-holder thoroughly as there was probably not enough diffusion time for the space-holder removal process. The APS was conducted in only several minutes (2-3 minutes); therefore, the duration should be studied further to find the optimum processing time.

\subsection{Mechanical properties}

Figure 9 shows the typical compressive stress-strain curve of the porous titanium. Meanwhile, the mean value

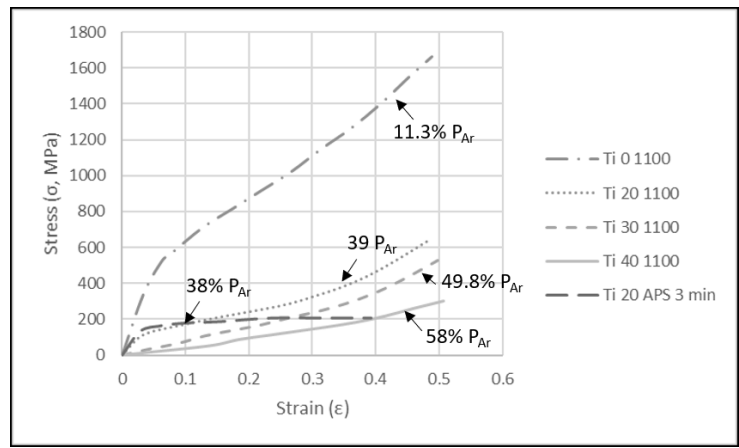

Figure 9. Compressive stress-strain curves of samples having various porosities obtained by Argon-sintering and APS.

and the standard deviation for the mechanical properties are shown in Table 3. Further analysis of the mechanical properties and the porosity is shown in Figure 10.

As shown in Figure 9, the porosity and the sintering process influence the compressive properties of porous titanium. For the Argon-atmospheric sintering route, the mechanical properties depend on the total porosity of the samples. Higher porosity as a result of more addition $\mathrm{NaCl}$ results in lower mechanical strength. The compressive behavior of porous titanium in this study is similar to cellular materials, consisting of the initial linear elastic region, the plateau region, and the densified region ${ }^{33}$. However, for the APS samples (Ti-20 APS 3min), the porosity content is similar to the Ti-20 1100 sample, but the compressive stress-strain curve is different. For the APS samples, the compressive curve only consists of the elastic region and the plateau region. Further, the specimen failed below $50 \%$ strain ( $40 \%$ in this study).

Table 3 and Figure 10 show the elastic modulus and yield strength are inversely proportional to the porosity. Not only the space-holder content but the manufacturing process also influences the mechanical properties. Hence, the porous titanium must have a similar characteristic to that of human bone. In other words, the mechanical properties should follow the cortical bone properties; the elastic modulus should be 
(a)

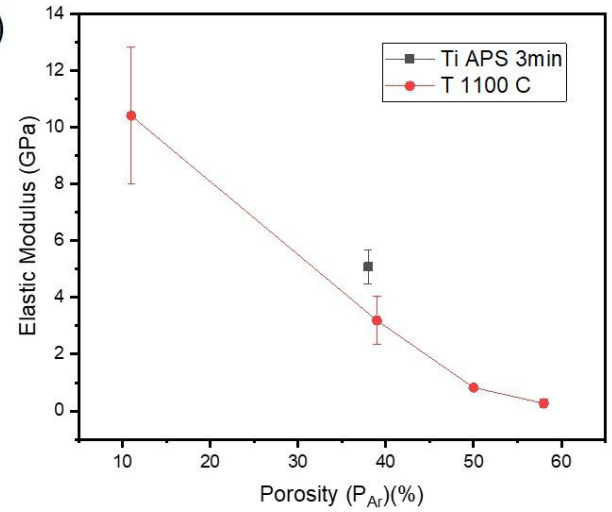

(b)

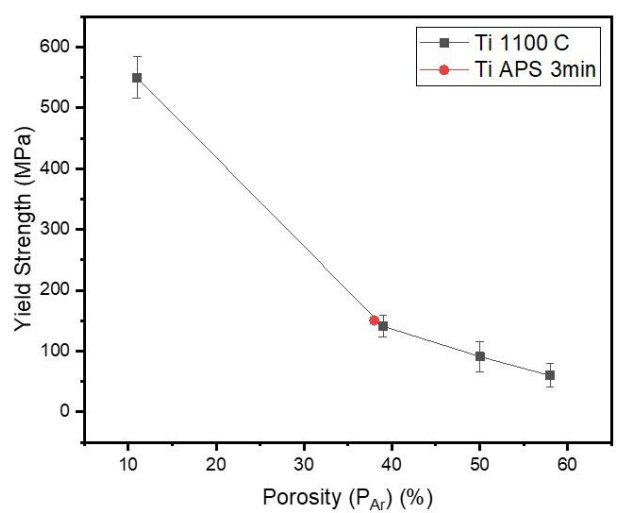

Figure 10. Compressive Mechanical Properties vs Porosity for porous titanium prepared by Argon-sintered and the APS; (a) elastic modulus, (b) yield strength.

Table 3. Mechanical Properties of Porous Titanium.

\begin{tabular}{ccc}
\hline Specimen & $\begin{array}{c}\text { Elastic Modulus } \\
(\mathrm{GPa})\end{array}$ & $\begin{array}{c}\text { Yield Strength } \\
(\mathrm{MPa})\end{array}$ \\
\hline Ti-0 1100 & $10.41 \pm 2.42$ & $550 \pm 33.9$ \\
\hline Ti-20 1100 & $3.19 \pm 0.85$ & $141 \pm 17.67$ \\
\hline Ti-30 1100 & $0.825 \pm 0.1$ & $90.95 \pm 24.53$ \\
\hline Ti-40 1100 & $0.27 \pm 0.14$ & $59.85 \pm 19.44$ \\
\hline Ti-20 APS 3min & $5.08 \pm 0.6$ & $150.5 \pm 4.95$ \\
\hline
\end{tabular}

in a range of 7-30 GPa, and the yield strength should be in a range of 120-160 $\mathrm{MPa}^{6,34}$. Therefore, Ti20-1100 and also Ti20 APS $3 \mathrm{~min}$ have fulfilled the mechanical properties requirement. These three porous titanium specimens show the possibility of being used as a permanently orthopedic implant. The microporosity and the macroporosity are also hypothesized to increase the osseointegration of porous titanium. Further study should be conducted to clarify this assumption.

\section{Conclusions}

It follows from this study that porous titanium can be prepared by both Argon-atmospheric sintering and APS process using $\mathrm{NaCl}$ as the space-holder. The porosity of the titanium is inversely proportional to the space-holder addition. The lower sintering temperature for the Argonatmospheric sintering and the short time of APS correlate with the formation of microporosity. The microporosity in the alloys would increase the value of total porosity, which made the obtained porosity higher than expected. Compared to the APS, Argon-atmospheric sintering was shown to produce a porous material with a denser pore wall, less contamination, and oxidation product reaction. However, the built-up APS machine, with several minutes of processing times, has shown a potential alternative method in titanium manufacturing. Based on the porosity and the mechanical properties, porous titanium with $20 \mathrm{wt} \%$ of $\mathrm{NaCl}$ proves promising to be used as orthopedic implants.

\section{Acknowledgements}

This research is fully supported by Direktorat Riset dan Pengabdian Masyarakat Universitas Indonesia (DRPM UI) through PUTI Doktor Research Grant No: NKB-682/UN2. RST/HKP.05.00/2020. The authors would also like to thank the Research Center for Metallurgy and Materials, Indonesia Institute of Sciences, for the laboratory facilities.

\section{References}

1. Vasconcellos LMR, Oliveira FN, Leite DO, Vasconcellos LGO, Prado RF, Ramos CJ, et al. Novel production method of porous surface Ti samples for biomedical application. J Mater Sci Mater Med. 2012;23(2):357-64.

2. Chen Q, Thouas GA. Metallic implant biomaterials. Mater Sci Eng Rep. 2015;87:1-57.

3. Civantos A, Beltrán AM, Domínguez-Trujillo C, Garvi MD, Lebrato J, Rodríguez-Ortiz JA, et al. Balancing porosity and mechanical properties of titanium samples to favor cellular growth against bacteria. Metals. 2019;9(10):1039.

4. Domínguez-Trujillo C, Ternero F, Rodríguez-Ortiz JA, Heise S, Boccaccini AR, Lebrato J, et al. Bioactive coatings on porous titanium for biomedical applications. Surf Coat Technol. 2018;349:584-92.

5. Niinomi M, Nakai M, Hieda J. Development of new metallic alloys for biomedical applications. Acta Biomater. 2012;8(11):3888903.

6. Pałka K, Pokrowiecki R. Porous Titanium Implants: a review. Adv Eng Mater. 2018;20(5):1700648.

7. Zhang L, Chen L. A review on biomedical titanium alloys: recent progress and prospect. Adv Eng Mater. 2019;21(4):1801215.

8. Daudt N, Bram M, Barbosa AC, Alves C Jr. Surface modification of highly porous titanium by plasma treatment. Mater Lett. 2015;141:194-7.

9. Vasconcellos LMR, Oliveira MV, Graça MLA, Vasconcellos LGO, Carvalho YR, Cairo CAA. Porous titanium scaffolds produced by powder metallurgy for biomedical applications. Mater Res. 2008;11(3):275-80.

10. Arifvianto B, Zhou J. Fabrication of metallic biomedical scaffolds with the space holder method: a review. Materials. 2014;7(5):3588-622.

11. Mediaswanti K, Wen C, Ivanova E, Berndt C, Malherbe F, Pham $\mathrm{V}$, et al. A review on bioactive porous metallic biomaterials. $\mathrm{J}$ Biomim Biomater Tissue Eng. 2013;18(1):2-8.

12. Dunand DC. Processing of titanium foams. Adv Eng Mater. 2004;6(6):369-76

13. Shbeh MM, Goodall R. Open celled porous titanium. Adv Eng Mater. 2017;19(11):1600664.

14. Oh I, Nomura N, Masahashi N, Hanada S. Mechanical properties of porous titanium compacts prepared by powder sintering. Scr Mater. 2003;49(12):1197-202. 
15. Oppenheimer S, Dunand DC. Solid-state foaming of Ti-6Al-4V by creep or superplastic expansion of argon-filled pores. Acta Mater. 2010;58(13):4387-97.

16. Singh R, Lee PD, Dashwood RJ, Lindley TC. Titanium foams for biomedical applications: a review. Mater Technol. 2010;25(34):127-36

17. Arifvianto B, Leeflang M, Zhou J. The compression behaviors of titanium/carbamide powder mixtures in the preparation of biomedical titanium scaffolds with the space holder method. Powder Technol. 2015;284:112-21.

18. Torres Y, Lascano S, Bris J, Pavón J, Rodriguez JA. Development of porous titanium for biomedical applications: a comparison between loose sintering and space-holder techniques. Mater Sci Eng C. 2014;37:148-55.

19. Caparrós C, Ortiz-Hernandez M, Molmeneu M, Punset M, Calero JA, Aparicio C, et al. Bioactive macroporous titanium implants highly interconnected. J Mater Sci Mater Med. 2016;27(10):151

20. Lee H, Liao J, Sivashanmugan K, Liu B, Su Y, Yao C, et al. Hydrothermal fabrication of highly porous titanium bio-scaffold with a load-bearable property. Materials. 2017;10(7):726.

21. Wen CE, Mabuchi M, Yamada Y, Shimojima K, Chino Y, Asahina T. Processing of biocompatible porous $\mathrm{Ti}$ and $\mathrm{Mg}$. Scr Mater. 2001;45(10):1147-53.

22. Xu W, Liu Z, Lu X, Tian J, Chen G, Liu B, et al. Porous Ti$10 \mathrm{Mo}$ alloy fabricated by powder metallurgy for promoting bone regeneration. Science China Materials. 2019;62(7):1053-64.

23. Tuncer N, Arslan G, Maire E, Salvo L. Investigation of spacer size effect on architecture and mechanical properties of porous titanium. Mater Sci Eng A. 2011;530:633-42.

24. Qiu G, Wang J, Cui H, Lu T. Mechanical behaviors and porosity of porous Ti prepared with large-size acicular urea as spacer. J SN Applied Sciences. 2019;1(1):107.

25. Kalantari SM, Arabi H, Mirdamadi S, Mirsalehi SA. Biocompatibility and compressive properties of Ti-6Al-4V scaffolds having $\mathrm{Mg}$ element. journal of the mechanical behavior of biomedical materials. 2015; 48:183-91.

26. Jakubowicz J, Adamek G, Dewidar M. Titanium foam made with saccharose as a space holder. J Porous Mater. 2013;20(5):113741.

27. Fang ZZ, Paramore JD, Sun P, Chandran KR, Zhang Y, Xia $\mathrm{Y}$, et al. Powder metallurgy of titanium-past, present, and future. Int Mater Rev. 2018;63(7):407-59.

28. Sugeng B, Bandriyana B, Salam R, Sujatno A, Dimyati A. Microstructure and phase analysis of Zirconia-ODS (Oxide Dispersion Strengthen) alloy sintered by APS with milling time variation. IOP Conference Series: Materials Science and Engineering. 2018;343(1):012035.

29. Bandriyana AD, Sujatno A, Salam R, Sumaryo P, Untoro BS. Microstructures and Hardness of the High Chromium Oxide Dispersion Strengthened Alloy Fe-25Cr-Y2O3 Sintered by the Arc Plasma Sintering (APS). IOP Conference Series: Materials Science and Engineering. 2018;333(1):012045.

30. Silalahi M, Sitompul H, Manalu JL, Dahlan K, Noviana D, Dimyati A. Novel technology on sinthesizing Mg-Zn biomaterial using arc plasma sintering. Asian Journal of Applied Sciences. 2017;5(3)

31. Supriadi S, Gatot M, Roseno F, Annur D, Suharno B, Dimyati A. Effect of arc plasma sintering process on formation of $\mathrm{TiO} 2$ surface layer for Ti-6Al-4V applications. In: AIP Conference Proceedings; New York: AIP Publishing LLC; 2020

32. Zhang K, Fan Y, Dunne N, Li X. Effect of microporosity on scaffolds for bone tissue engineering. Regen Biomater. 2018;5(2):115-24.

33. Khodaei M, Fathi M, Meratian M, Savabi O. The effect of porosity on the mechanical properties of porous titanium scaffolds: comparative study on experimental and analytical values. Mater Res Express. 2018;5(5):055401.

34. Li Y, Yang C, Zhao H, Qu S, Li X, Li Y. New developments of Ti-based alloys for biomedical applications. Materials. 2014;7(3):1709-800. 